\title{
Potential of Bacteriophage Therapy: A Double Edge Sword to Combat COVID-19 and Associated Pulmonary Bacterial Infections
}

\author{
KANIKA BHARGAVA, G. NATH ${ }^{1}$, G. K. ASERI AND NEELAM JAIN²* \\ Amity Institute of Microbial Technology, Amity University Rajasthan, Jaipur 303002, ${ }^{1}$ Institute of Medical Sciences, \\ Banaras Hindu University, Varanasi $221005,{ }^{2}$ Amity Institute of Biotechnology, Amity University Rajasthan, Jaipur
} 303002, India

Bhargava et al.: Bacteriophage Therapy in COVID-19 Pandemic

\begin{abstract}
The Coronavirus Disease 2019 pandemic has wreaked havoc on global health infrastructure and personnel, resulting in enormous misery, deaths and economic stagnation. Severe Acute Respiratory SyndromeCoronavirus-2 respiratory infections are frequently worsened by secondary bacterial infections and co-infections due to prolonged hospitalizations; resulting in irreversible lung damage, respiratory failure, cardiac arrest and death. The high mortality rate of Coronavirus Disease 2019 patients is primarily due to multi drug resistant microbial (viral/bacterial) infections, unrestrained inflammatory response and delayed antibody production. The superfluous use of broad spectrum antimicrobial drugs as the last resort has further aggravated the Coronavirus Disease 2019 crisis by contributing to the global antimicrobial resistance. To overcome these hurdles for effective treatment of Coronavirus Disease 2019 and associated bacterial infections, phage therapy seems to be promising due to a lack of effective antiviral drugs and antimicrobial-resistant superadded bacterial infections. Prior studies suggest that when phages, their cocktails and endolysins are administered alone or in synergism with antibiotics through nebulization or through intravenous and intraperitoneal injections have exhibited greater antibacterial potential to combat even Multidrug-Resistant pulmonary bacterial infections. Bacteriophages and phagicin have also shown potent antiviral activity by triggering the production of antiviral cytokines. Many studies have also indicated phage mediated antiviral immunity by lowering Nuclear Factor Kappa B activation and reactive oxygen species production. Phage display technique can serve as a promising approach for Coronavirus Disease 2019 vaccine development through production of Severe Acute Respiratory Syndrome-Coronavirus-2 specific antibodies. This review illustrates the potential of phage therapy as a double edged sword to combat both Coronavirus Disease 2019 as well as associated bacterial infections.
\end{abstract}

Key words: Bacteriophages, viral infections, Coronavirus Disease 2019 , pulmonary bacteria, secondary infection, co-infection

In the last two decades, there have been six significant viral outbreaks which include Severe Acute Respiratory Syndrome-Coronavirus (SARS-CoV) (2002), Hemagglutinin Type 1 and Neuraminidase Type 1 (H1N1) Influenza (2009), Middle East respiratory syndrome coronavirus (MERS-CoV) (2012), Ebola virus (2013), Zika virus (2015) and SARS-CoV-2 also known as Coronavirus Disease 2019 (COVID-19) that have contributed to the worldwide turmoil. Out of these, four of them (SARS-CoV, H1N1 Influenza, MERS-CoV and SARS-CoV-2) resulted in severe viral respiratory disease ${ }^{[1]}$. Clinical presentation for COVID-19 infection ranges from asymptomatic to severe viral pneumonia with respiratory failure, often

*Address for correspondence

E-mail: njain1@jpr.amity.edu

November-December 2021 resulting in death ${ }^{[2]}$. The COVID-19 virus is estimated to have caused approximately 196 million infections and 4.2 million deaths and the number of infections and death toll is still mounting ${ }^{[3]}$. The emphasis during viral pandemic is primarily on viral infection treatment; however, associated bacterial infections that develop in patients after or during the primary infection quite often turns unnoticed. So far, multiple studies have examined

This is an open access article distributed under the terms of the Creative
Commons Attribution-NonCommercial-ShareAlike 3.0 License, which
allows others to remix, tweak, and build upon the work non-commercially,
as long as the author is credited and the new creations are licensed under
the identical terms Accepted 02 November 2021 Revised 02 September 2021 Received 27 April 2021 Indian J Pharm Sci 2021;83(6):1081-1093 
the epidemiological and clinical features of COVID-19, but data regarding associated bacterial infections is still quite limited ${ }^{[4]}$.

Respiratory infections due to viruses predispose patients to bacterial infections. The 1918 Spanish flu outbreak, the 2003 SARS-CoV epidemic and the 2009 H1N1 Influenza pandemic were also associated with bacterial infections, which have resulted in increased morbidity and mortality ${ }^{[5,6]}$.

According to a recent study, $7 \%$ of COVID-19 positive cases developed an extremely heterogeneous bacterial infection, with a higher prevalence in intensive care settings due to nosocomial infections and invasive ventilation $^{[7]}$. Fu et al. reported secondary bacterial infection in $13.9 \%$ of Intensive Care Unit (ICU) patients ${ }^{[4]}$. A retrospective analysis conducted in Wuhan, China, stated that the proportion of secondary bacterial infection in lungs was $86.3 \%$, bloodstream $34.3 \%$ and urinary tract $7.8 \%$ respectively, in COVID-19 patients ${ }^{[2]}$. In addition, another retrospective analysis revealed that $15 \%$ of hospitalized COVID-19 patients developed secondary infections, which contributed to $50 \%$ of the death toll ${ }^{[8]}$.

Diagnosis of superadded bacterial infections in this pandemic is highly complicated. Hence, broad-spectrum antibiotics are used prophylactically to reduce their risk, ultimately contributing to the prevalence of AntiMicrobial Resistance (AMR) globally ${ }^{[7]}$. However, in this challenging time and with the advent of Multi-Drug Resistant (MDR) bacterial infections, bacteriophages can be introduced as they are highly specific, selflimiting, self-replicating, naturally abundant, display low toxicity, evolve naturally and thus ultimately undergo degradation within patient's body ${ }^{[9,10]}$.

\section{PULMONARY BACTERIAL INFECTIONS DURING COVID-19}

Secondary bacterial infections occur in addition to the primary infection, where bacterial pneumonia follows acute viral influenza ${ }^{[11]}$. Co-infections occur simultaneously due to multiple pathogens and are the most prevalent complications during a pulmonary viral pandemic, resulting in mixed viral and bacterial pneumonia features ${ }^{[12]}$. COVID-19 patients with comorbidities and extended hospitalization in ICU are susceptible to nosocomial infections including Ventilator-Associated Pneumonia (VAP), followed by bacteremia with sepsis and also SARS-CoV-2associated immune dysfunction. This association between COVID-19 and superinfection can be probably due to major lung impairment triggered by viral reproduction resulting in cytokine storm and inflammatory reactions. The impaired immune response caused by primary virus-related disease promotes secondary bacterial infections and co-infections, leading to a high rate of mortality and morbidity. It is projected that 1 in 7 COVID-19 patients admitted in hospitals are predisposed to secondary infections ${ }^{[13]}$. The antibiotics used in high doses as a last resort for such bacterial illnesses can be counter-productive due to several side effects and emerging drug resistance. Secondary bacterial infections in COVID-19 are predominantly caused by Streptococcus pneumoniae, Staphylococcus aureus, Klebsiella pneumoniae, Pseudomonas aeruginosa, Escherichia coli and Acinetobacter baumannii ${ }^{[14,15]}$. Several theories have been elucidated for the development of concomitant bacterial infection in patients with a primary pulmonary viral infection, including immunological host modifications, structural disruption promoting easy dissemination and impaired clearance of mucus within the lungs ${ }^{[1]}$. Secondary bacterial infections are facilitated by the impaired mucociliary function of the upper respiratory tract caused by primary pulmonary viral insult ${ }^{[16]}$. Bacterial spread is facilitated by thickened mucus, which prevents immune cell penetration, as well as immunosuppression of the host's immune system as a result of primary viral infection ${ }^{[17]}$. Secondary bacterial infection further damages the epithelial cell layer, inhibiting its repair and regeneration, thus fostering disease severity, morbidity and mortality ${ }^{[18]}$. In addition, surfactant disruption and respiratory tract cell sloughing can provide access and essential nutrients enabling bacteria to proliferate rapidly ${ }^{[19]}$. The addition of bacterial infection augments airway inflammation and alveolar consolidation, increasing the severity of the disease ${ }^{[20]}$.

\section{AMR BACTERIAL PREDISPOSITION TO PRIMARY VIRAL INFECTION}

AMR is a global problem, with 2.8 million people infected and 35000 people dying each year in the United States ${ }^{[21]}$ and the indiscriminate use of antibiotics during COVID-19 will exacerbate the matter. MDR bacteria are becoming more common and our ability to eliminate them is dwindling, thereby increasing our susceptibility to bacterial infections, especially during pandemics. Antiviral and anti-inflammatory properties of azithromycin and doxycycline have been empirically used to treat COVID-19 infections; besides, they may also counter co-infection, but their injudicious use may further lead to the emergence of MDR strains. Secondary 
infections and co-infections have irreversible effects during viral pandemics, especially in high-risk groups, including immunodeficient or immunosuppressed groups $^{[22]}$. Patients vulnerable to pulmonary viral infections (Influenza, SARS and COVID-19) face the greatest risk of being infected with superbugs ${ }^{[1,23,24]}$. One of the classical reports of bacterial infection arising concurrently or immediately following comes from the 1918 influenza pandemic, in which bacterial coinfection was responsible for the majority of fatalities ${ }^{[5]}$. Approximately 300000 people died worldwide due to the $2009 \mathrm{H} 1 \mathrm{~N} 1$ pandemic, with bacterial pneumonia accounting for $30-55 \%$ of $\operatorname{cases}^{[25]}$. Respiratory viruses associated with bacterial co-infection reported are influenza, Human Parainfluenza Virus (HPIV), Human Metapneumovirus (HMPV), rhinovirus, adenovirus and Syncytial Respiratory Virus (SRV) [26,27]. Human coronavirus NL63, Human Bocavirus (HBoV), H1N1 and H5N1 influenza viruses, SARS, coronavirus associated with MERS and COVID-19 are examples of emerging pulmonary viruses where bacterial infections result in complications ${ }^{[26]}$. Research conducted in Wuhan, China, in hospitalized patients with COVID-19 reported that MDR Acinetobacter baumannii and Klebsiella pneumoniae induced secondary infection ${ }^{[2]}$, which resulted in further complications. A weakened immune system is a significant risk factor for MDR bacterial infections in patients with severe COVID-19 ${ }^{[28]}$. Another study reported that $33 \%$ of COVID-19 patients acquired MDR Enterobacteriaceae, Vancomycin Resistant Enterococci (VRE), Enterococcus faecium and MDR Pseudomonas aeruginosa ${ }^{[29]}$. Patel et al. also reported the dissemination of MDR gram-negative bacteria among COVID-19 patients in Maryland, USA ${ }^{[30]}$. A list of bacterial infections with the virus during COVID-19 and other previous viral pandemics is shown in Table $1^{[31-59]}$. As broad-spectrum antibiotic prophylaxis does not support severe secondary and co-infections in COVID-19 patients, alternative antibacterial therapies such as bacteriophages can be used to avoid further complications and counter global AMR.

\section{BACTERIOPHAGES: A RESURGENT ARSE- NAL}

Bacteriophages, also known as phages, are ubiquitous viruses that selectively infect, replicate inside the bacterial cell and kill it without affecting any host eukaryotic cells ${ }^{[60]}$. The administration and exploitation of phages for treating pathogenic bacteria dates back to a century. The Sacred River Ganges of India is one of the major repositories of bacteriophages, particularly at Gomukh ${ }^{[61]}$. In addition, they have been found in rivers, sewage, wastewater and hospitals worldwide, as well as human and animal gastrointestinal tract and wherever their host survives ${ }^{[62]}$. The resurgence of bacteriophage therapy as a potent weapon to combat AMR during pandemic times appears to be a rational measure in light of the rapid rise in MDR pathogens globally, as well as a decrease in the discovery of new antibacterial compounds. Hence, they can be utilized either alone or in combination with antibiotics to treat resistant bacteria ${ }^{[63]}$.

Bacteriophage therapy utilizes phages that specifically docks on host-pathogen for its replication, resulting in the release of phage progeny via lysis of its host ${ }^{[64]}$. Bacteriophages replicate via two types of cycles, i.e. lytic and lysogenic cycles. Bacteriophages attach and invade susceptible specific bacteria in these two groups via specific bacterial receptors (fig. 1A) ${ }^{[65]}$. Specific phages infect and take over the replication process of their exclusive host cells (bacteria) during the lytic cycle, producing viral genomes and proteins (fig. 1E). Following that, phage assembly and packaging culminate in the release of new progeny via cell lysis, which would further colonize other bacterial hosts (fig. 1F) ${ }^{[66]}$. In the lysogenic cycle, bacterial biochemical machinery is infiltrated, where viral genetic material is incorporated (fig. 1B) into the host genome and the virus chromosome is conveyed to daughter cells via cell division (fig. 1C) ${ }^{[60]}$. The incorporated viral DNA (prophage) remains inactive but is replicated with each cell division of its host ${ }^{[67]}$. The prophage becomes activated under the correct environment, initiating the lytic cycle and releasing new progeny ${ }^{[68]}$.

\section{BACTERIOPHAGE THERAPY: A DOUBLE EDGE SWORD AGAINST COVID-19 PAN- DEMIC}

Phage therapy was originally designed to kill bacteria. Previously, little was known about the biology of phages and their interaction with bacteria ${ }^{[64]}$. With the advancement of biomedical technology new details about bacterial and viral biology (fig. 2) has been revealed and a strong resurgence of phage therapy has been observed due to the emergence of AMR during pandemics on a global platform ${ }^{[69]}$. Bacteriophages have great potential to tackle bacterial infections either alone or in combination with antibiotics ${ }^{[61]}$ and through its lytic enzymes as well as can be used against viruses via phage display technique, thus leading to a prospective roadmap to tackle COVID-19 and associated bacterial 
www.ijpsonline.com

TABLE 1: PULMONARY VIRAL AND ASSOCIATED BACTERIAL INFECTIONS

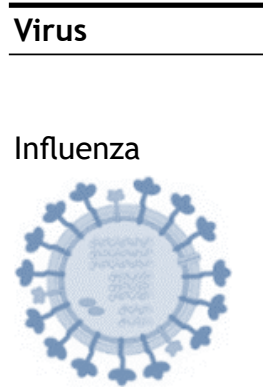

Metapneumovirus

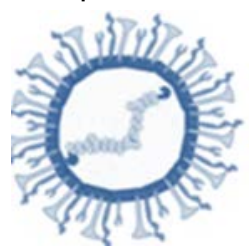

Respiratory syncytial virus

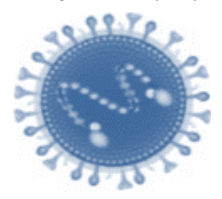

Adenovirus

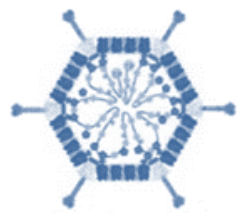

Parainfluenza

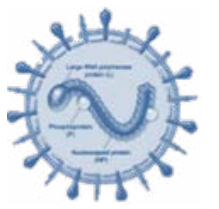

Rhinovirus

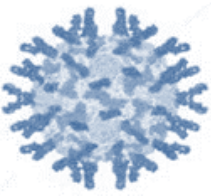

SARS

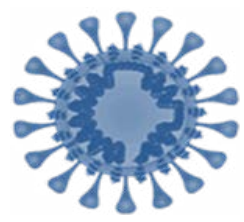

MERS

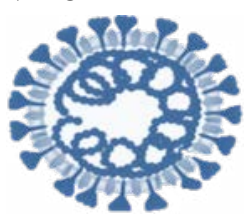

Streptococcus pneumonia, Haemophilus influenzae, Enterococcus spp., Brucella spp., Streptococcus pyogenes

Pseudomonas aeruginosa

Haemophilus influenzae, Chlamydia trachomatis

Streptococcus pneumoniae, Haemophilus influenzae

Streptococcus agalactiae

Streptococcus pneumoniae, Mycoplasma pneumoniae

Staphylococcus aureus

Chlamydophila pneumoniae

Mycoplasma pneumoniae

MRSA

Mycobacterium tuberculosis
Secondary infections

[41]

Infection type

Co-infections

Co-infections

References

Secondary infections

[35]

Co-infections

[36]

Co-infections

[37]

[38]

Co-infections

[38]

Secondary infections

[39]

Secondary infections

[40]

Co-infections

[42]

Secondary infections

[43]

Co-infections

[44]

Co-infections

[45]

Co-infections

[46]

Co-infections

[6]

Co-infections

[6]

Secondary infections

$[47,48]$

Co-infections

[49] 
Acinetobacter baumannii, Klebsiella pneumoniae

Mycoplasma pneumoniae, Legionella pneumophila, Streptococcus pneumoniae

Staphylococcus aureus

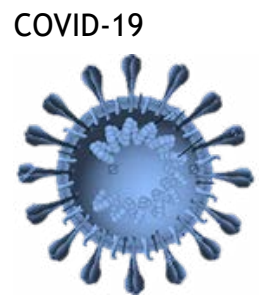

Haemophilus influenza, Staphylococcus aureus

Enterobacter cloaca, Acinetobacter baumannii

Pseudomonas aeruginosa, Staphylococcus aureus

Staphylococcus aureus, Pseudomonas aeruginosa, Klebsiella pneumoniae, Escherichia coli

Klebsiella pneumoniae, Klebsiella oxytoca,

Staphylococcus aureus, Enterobacter cloacae, Enterobacter aerogenes, Pseudomonas aeruginosa

Klebsiella pneumoniae, Acinetobacter baumannii

Staphylococcus aureus, Klebsiella oxytoca,
Co-infections

Secondary infections

Co-infections

[52]

Co-infections

[53]

Secondary infections

Secondary infections

Secondary infections

[56]

Secondary infections

Secondary infections

[58]

Stenotrophomonas maltophilia, Haemophilus influenza \& Haemophilus parainfluenzae

Co-infections

[59]

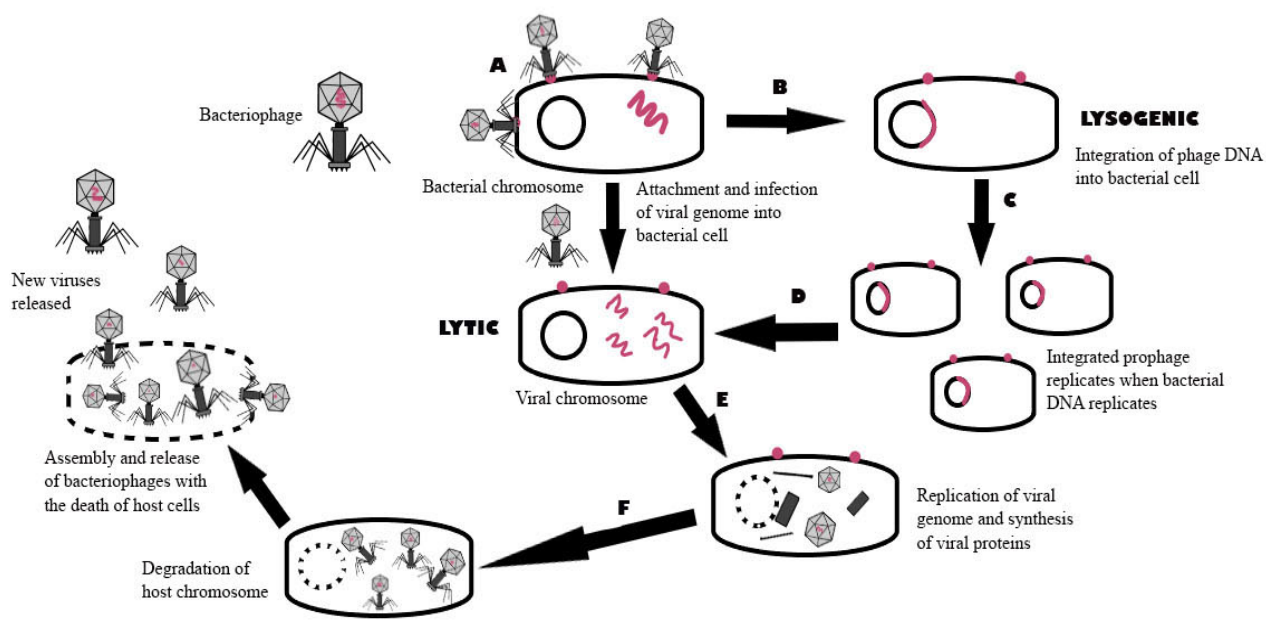

Fig. 1: Mechanism of action (Lytic and lysogenic cycle) of bacteriophages

infections during COVID-19 pandemic.

\section{Phage therapy against secondary pulmonary bacterial infections:}

As AMR infections continuously rise, adjunct therapeutic options are required, inspiring renewed interest in bacteriophage therapy. Waters et al. reported high effectivity of phage therapy against recalcitrant chronic lung infection caused by Pseudomonas aeruginos $a^{[70]}$. A recent study investigated the use of pre optimized phages as an alternative therapy for lung infections caused by carbapenem-resistant Acinetobacter baumannii strains in COVID-19 patients and showed improvement in infection by reduction of bacterial load ${ }^{[71]}$. A case report describes a favorable phage therapeutic response in a cystic fibrosis patient, confirming its efficacy against Staphylococcus aureus $^{[72]}$. The phage therapeutics studies including bacteriophages and lysins for most frequent pulmonary bacteria causing secondary infections are listed in Table 2. Recently, the U.S. Food and Drug Administration (FDA) have approved clinical trials for personalized intravenous phage therapy intended for COVID-19 patients $^{[73]}$ suffering with bacteremia, pneumonia or septicemia due to MDR bacterial coinfections by Pseudomonas aeruginosa, Acinetobacter baumannii or Staphylococcus aureus ${ }^{[74-100]}$.

\section{Phage synergism with antibiotics:}

Bacteriophages have been used synergistically with antibiotics to treat AMR infections. The use of phages in synergism with antibiotics has proven to be extremely efficient in the treatment of antibioticresistant opportunistic bacteria that cause polymicrobial 


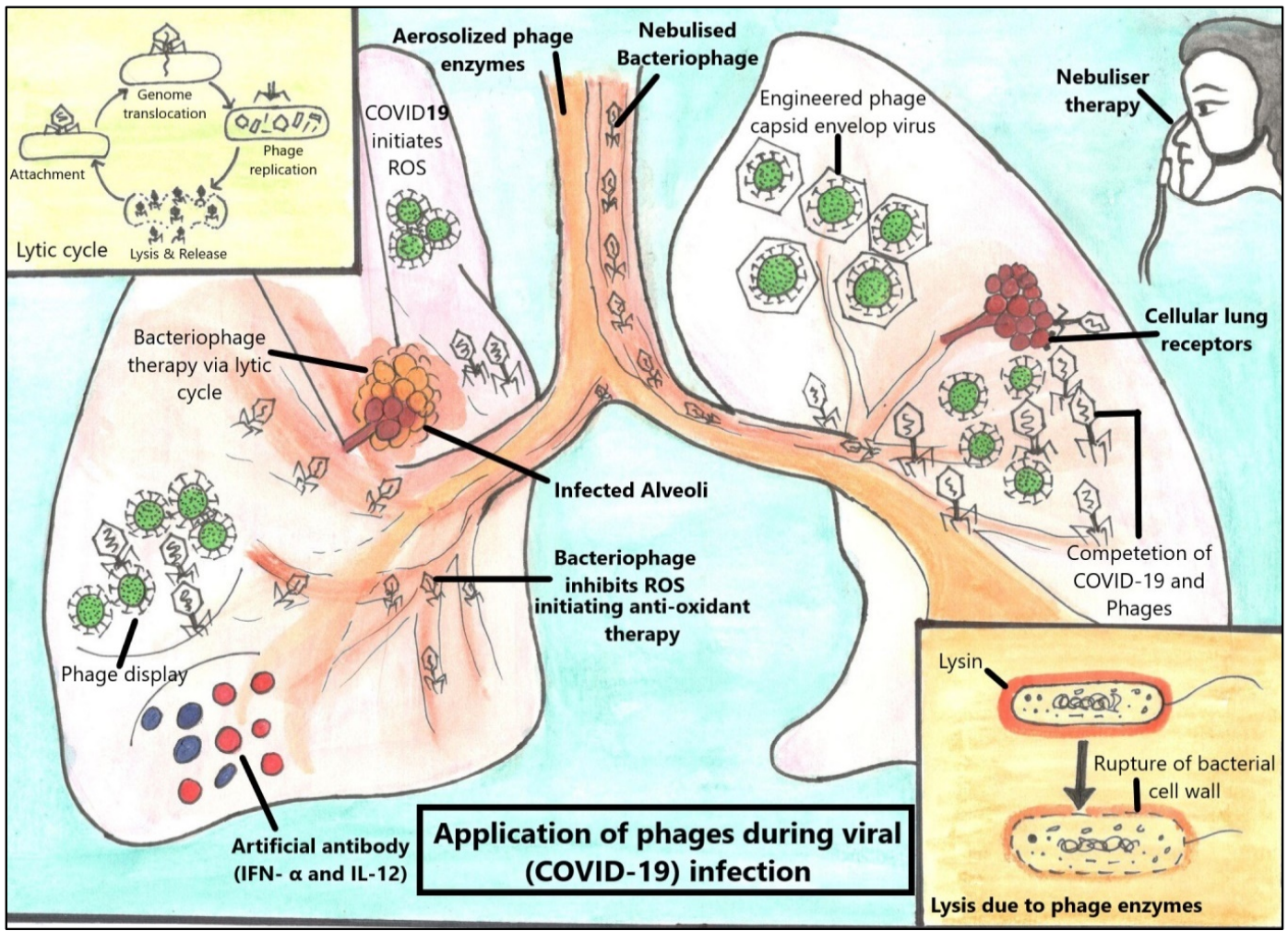

Fig. 2: Future perspectives of bacteriophage therapy during COVID-19 and associated pulmonary bacterial infections

TABLE 2: PHAGE THERAPY AGAINST SECONDARY PULMONARY BACTERIAL INFECTIONS

\begin{tabular}{|c|c|c|c|c|c|}
\hline Secondary Bacterial Infection & Subject & $\begin{array}{l}\text { Phages/Lysin } \\
\text { +/- Antibiotic }\end{array}$ & Phage Family & Administration & Reference \\
\hline Multi-Drug & & Phage cocktail PaAH2ФP & & Intratracheal/ & \\
\hline $\begin{array}{l}\text { Resistant Pseudomonas } \\
\text { aeruginosa Pneumonia }\end{array}$ & Murine & $\begin{array}{c}\text { (103), PsBAP5Ф2 (130) } \\
\text { and PAФ134+Meropenem }\end{array}$ & Myoviridae & $\begin{array}{l}\text { Intraperitoneal } \\
\text { injection }\end{array}$ & [74] \\
\hline $\begin{array}{l}\text { Pseudomonas aeruginosa } \\
\text { Ventilator-associated } \\
\text { Pneumonia }\end{array}$ & Human & $\begin{array}{c}\text { AB-PA01 (Cocktail } \\
\text { of four lytic } \\
\text { phages)+antibiotics }\end{array}$ & $\begin{array}{l}\text { Myoviridae } \\
\text { and } \\
\text { Podoviridae }\end{array}$ & $\begin{array}{l}\text { Intravenous and } \\
\text { nebulization }\end{array}$ & [75] \\
\hline $\begin{array}{l}\text { Imipenem resistant } \\
\text { Pseudomonas aeruginosa } \\
\text { bacteremia }\end{array}$ & Mice & $\begin{array}{c}\text { Phage } \emptyset \mathrm{A} 392 \text { and phage } \\
\varnothing 1093 \text { cocktail }\end{array}$ & Myoviridae & $\begin{array}{l}\text { Intraperitoneal } \\
\text { injection }\end{array}$ & [76] \\
\hline $\begin{array}{l}\text { Pseudomonas aeruginosa, } \\
\text { Staphylococcus aureus, } \\
\text { Streptococcus pyogenes, } \\
\text { Proteus and Escherichia coli }\end{array}$ & Human & $\begin{array}{c}\text { Pyophage (Cocktail of } \\
\text { phages) }\end{array}$ & $\begin{array}{c}\text { Podoviridae \& } \\
\text { Myoviridae }\end{array}$ & $\begin{array}{l}\text { Nebulization \& } \\
\text { sanitizing of nose } \\
\text { and throat }\end{array}$ & [77] \\
\hline $\begin{array}{l}\text { Burkholderia cepacia chronic } \\
\text { lung infections }\end{array}$ & $\begin{array}{c}\text { Galleria } \\
\text { mellonella } \\
\text { larvae }\end{array}$ & $\begin{array}{c}\text { ФKS12, } \\
\text { ФKS14+Meropenem, } \\
\text { Ciprofloxacin, and } \\
\text { Tetracycline }\end{array}$ & Myoviridae & $\begin{array}{l}\text { Hamilton syringe } \\
\text { injection }\end{array}$ & [78] \\
\hline $\begin{array}{l}\text { Burkholderia cepacia complex } \\
\text { respiratory infections }\end{array}$ & Mice & ФKS4-M, ФKS14, Ф KS12 & Myoviridae & $\begin{array}{l}\text { Intraperitoneal \& } \\
\text { Aerosolized }\end{array}$ & [79] \\
\hline $\begin{array}{l}\text { Burkholderia cepacia and } P . \\
\text { aeruginosa Pneumonia }\end{array}$ & In vitro & $\begin{array}{c}\text { ФKS4- } M, \Phi K S 14, \text { and } \\
\text { cocktails of } \Phi K Z / D 3 \text { and } \\
\text { ФKZ/D3/KS4-M }\end{array}$ & Myoviridae & $\begin{array}{c}\text { Spray-dried } \\
\text { respirable } \\
\text { powders delivered } \\
\text { from an Aerolizer } \\
\text { dry powder inhaler } \\
\text { (DPI) }\end{array}$ & [80] \\
\hline $\begin{array}{l}\text { K. pneumoniae B5055- } \\
\text { mediated lobar pneumonia }\end{array}$ & Mice & ФSS & Podoviridae & $\begin{array}{l}\text { Intraperitoneal } \\
\text { injection }\end{array}$ & [81] \\
\hline
\end{tabular}


Multidrug-Resistant Klebsiella pneumoniae ST258 bacterimia Carbapenem-

resistant Acinetobacter

baumannii (CRAB)

Multidrug resistant $A$.

baumannii (MDRAB)

Carbapenem-

resistant Acinetobacter

baumannii (CRAB) associated

pneumonia

Extensively drug-resistant

Acinetobacter baumannii

(XDRAB ) bacteraemia

Acinetobacter baumannii

Bacteraemia

Acinetobacter baumannii and

Pseudomonas aeruginosa

Extraintestinal Escherichia

coli Ventilator-associated

Pneumonia

Streptococcus pneumoniae

Community- Acquired

Pneumonia

Streptococcus pneumoniae

Penicillin-resistant

Streptococcus pneumoniae

Streptococcus pneumoniae

bacteremia

\section{Staphylococcus aureus}

Methicillin-resistant

Staphylococcus aureus

induced ventilator-associated

pneumonia

Methicillin-resistant and

vancomycin-intermediate

Staphylococcus aureus causing

acute Pneumonia

\section{Staphylococcus aureus}

Methicillin-

resistant Staphylococcus

aureus bacteremia

MRSA Staphylococcus aureus

septicemia

Staphylococcus aureus

Mixed infections by MRSA,

Vancomycin-Intermediate $S$.

aureus (VISA), Streptococcus

pyogenes and S. pneumoniae
Mice

Pharr ФKpNIH-2

Human

Phage cocktail

(ФAb124+ФAb121)

Mice

ФPD-6A3/Endolysin Ply6A3

Mice

ФSH-Ab 15519

ФvB_AbaM_3054 ФvB AbaM_3090

Mouse

Mouse

Caenorhabditis

elegans

Mice

In vitro

ФSPSL1

In vitro

$\Phi C p-1$

In vitro

Endolysins Pal and Cpl-1

Chimeric phage lysin

Mice

Cpl-711 (Cpl-1 and Cpl7S)

Human

Rat

Cocktail (ФK, Ф3A, 2002

and 2003

Mouse

AB-SA01 Component
Phages

In vitro

ФSA5+Gentamicin

Mouse

Mouse

Mouse

Mice

$$
\text { LysGH15 }
$$

Chimeric lysin

(ClyS)+Oxacillin

Recombinant phage

endolysin, SAL-1

Endolysin
Podoviridae

Siphoviridae

Podoviridae \& Myoviridae

Podoviridae

Podoviridae

bacteriophages

PlySs2+Mupirocin

Intraperitoneal
Intraperitoneal injection
Myoviridae

Myoviridae

Myoviridae

Myoviridae

Siphoviridae

Podoviridae

Podoviridae

Podoviridae

Myoviridae

Myoviridae

Nebulized

(“aerophages”)

Myoviridae

Intraperitoneal (IP) injection

Myoviridae

Intraperitoneal
injection

Intraperitoneal injection

Bacteriophage suspension

Intranasal Instillation

Bacteriophage

Bacteriophage suspension

Bacteriophage suspension

Intraperitoneal injection

Bacteriophage suspension injection

Myoviridae injection

Myoviridae

Intravenous injection

Siphoviridae 
biofilm-associated diseases ${ }^{[101]}$. Aslam et al. reported clinical experience with phage therapy combined with antibiotics in three patients with life-threatening MDR infections caused by Pseudomonas aeruginosa and Burkholderia dolosa, two of whom improved ${ }^{[102]}$. According to a researcher, treatment of phage combined with ceftazidime appears to eradicate aortic graft infection caused by Pseudomonas aeruginosa with no evidence of recurrence ${ }^{[103]}$. An ex vivo study was performed on a human airway epithelial cell line model to test the efficacy of combined bacteriophage and ciprofloxacin treatment in preventing Pseudomonas aeruginosa infection, where co-administration efficiently prevented bacterial regrowth and maintained epithelial cell integrity ${ }^{[104]}$.

\section{Role of bacteriophage lytic enzyme:}

Over time, many phage-derived hydrolytic enzymes, such as endolysins and ectolysin, have been discovered that disrupt the bacterial peptidoglycan cell wall, eventually killing the bacteria ${ }^{[105]}$. The bacterial cell wall comprises peptidoglycan polymer chains comprised of a disaccharide repeat of glycan strands ( $\mathrm{N}$-acetyl glucosamine and $\mathrm{N}$-acetylmuramic acid, linked by $\beta$ $(1 \rightarrow 4)$ glycosidic bonds). Lysins are glycosidases and when employed exogenously in pure forms, they cause immediate osmotic lysis and bacterial death. They are also referred to as enzybiotics due to their antibacterial activity. Lysins kill bacteria rapidly upon contact and they are specific to the target pathogen ${ }^{[106]}$. Furthermore, lysin does not disrupt the natural microbiome. Thus, resistance development is highly improbable and it can be used alone or synergistically with antibiotics ${ }^{[107]}$. Larpin et al. demonstrated in vitro optimal bactericidal activity of phage lysin PlyE146 against Escherichia coli, Pseudomonas aeruginosa and Acinetobacter baumannii strains, making it a promising therapeutic agent against infections caused by these bacteria ${ }^{[108]}$. Lysins can be an effective therapeutic tool against bacterial infections after standardizing the dose and regimen.

\section{Potential role of phage therapy against SARS- CoV-2:}

Phagicin is synthesized during viral (bacteriophage) replication and can also be extracted by disrupting the phage particles ${ }^{[63]}$. Phagicin has been shown to exhibit antiviral properties (interfering with viral DNA intracellular replication) against the Herpes Simplex Virus (HSV) and Vaccinia viruses ${ }^{[109]}$. As a result, its antiviral properties make it suitable for use against other pathogenic viruses, including SARS-CoV-2. According to a researcher, a genetically engineered bacteriophage capsid envelops the influenza virus, inhibiting it from adhering to lung tissues and thus preventing infection ${ }^{[110]}$. Because the influenza virus shares few genomic similarities to that of COVID-19; hence, the same could be applied to it. Antiviral drugs for COVID-19 (favipiravir and remdesivir) are not particularly efficient and their mode of action is by inhibiting Ribonucleic Acid (RNA)-dependent RNA polymerase ${ }^{[111]}$. Therefore, they do not halt virus attachment to the host cell and do not prevent the initial stage of infection (entry of the virus into the host cell), causing disruption of the alveolar epithelium (Pneumocyte type II) ${ }^{[12]}$. Also, when phages are introduced after a primary viral infection, they often compete with the pathogenic virus for the cellular receptors and restrict their infectivity ${ }^{[113]}$. Nuclear Factor Kappa B $(\mathrm{NF}-\mathrm{\kappa} \mathrm{B})$ is a widely expressed transcription factor induced by SARS-CoV-2 and is involved in inflammatory and immunological responses ${ }^{[14]}$. However, bacteriophages significantly reduce or abolish the triggering of $\mathrm{NF}-\kappa \mathrm{B}$ activation ${ }^{[115]}$. A respiratory pathogen (bacteria and/or viruses) infecting the lung is often associated with inflammation and cell death caused by excessive production of Reactive Oxygen Species (ROS) ${ }^{[16]}$. However, phage and phage proteins inhibit ROS production and exhibit antimicrobial activities via anti-oxidant therapy ${ }^{[117]}$. Another data suggests the exploitation of phages where they drive antiviral activity by promoting the production of antiviral cytokines like Interferon Alpha (IFN- $\alpha$ ) and Interleukin-12 (IL-12) ${ }^{[115]}$.

\section{Phage display: a technique to counter bacterial and viral infection}

COVID-19 pandemic has enforced us to explore alternative therapies to combat SARS-CoV-2 and prevent associated microbial infections. Phage display is an alternative to hybridoma technique for manufacturing therapeutic Monoclonal Antibodies (MABs) against a specific viral or bacterial antigen ${ }^{[18]}$. The phage display technique can be utilized in two ways: to decrease the pulmonary bacterial infection and/or to efficiently produce antibodies against pulmonary viral (COVID-19) infections ${ }^{[119]}$. It is a method of producing phage-displayed vaccines in which a protein gene of interest is encoded into the phage coat protein, leading the phage to exhibit the protein on the exterior while carrying it on the inside. Thus, it can provide SARSCoV-2 positive patients more time to build their unique 
immune response against COVID-19, allowing them to escape the damage caused by an overly sensitive immune system ${ }^{[65]}$. Phage display technique has been used to isolate specific mAbs against viruses such as influenza $\mathrm{A}^{[120]}$ and human immunodeficiency virus (HIV) ${ }^{[121]}$. A latest report suggests CR3022 (a SARSCoV-1/2 antibody) isolated from a phage display library exhibited potent SARS-CoV-2 neutralizing activity arising from destabilization of the spike trimer ${ }^{[122]}$. The use of biopanning technique has led to the recognition of human monoclonal antibodies (hmAbs) from eight large phage-displayed $\mathrm{VH}, \mathrm{scFv}$ and Fab libraries including $\mathrm{mAb}$, IgG1 ab1 targeted against the receptor binding domain (RBD) of the spike protein of SARS-CoV-2. The IgG1 ab1 effectively neutralized live SARS-CoV-2 in human angiotensin-converting enzyme 2 (ACE2) expressing transgenic mice mode ${ }^{[123]}$. The studies thus emphasize the importance of phage display to tackle global health issues in the era of COVID-19 and future pandemics of constantly emerging and re-emerging microbes. It is rightly said that 'A diamond can cut a diamond', likewise in this prevailing pandemic of COVID-19, when even antiviral medicines are not very effective, bacteriophages can be a promising tool to combat SARS-CoV-2 infections.

\section{CHALLENGES IN PHAGE THERAPY}

Bacteriophages are used to treat bacterial infections as an alternative to antibiotics with an emerging crisis of AMR. Phage cocktails are therefore used to treat a broad range of secondary bacterial infections. But, the guidelines for the use of bacteriophages have yet to be properly formulated, as most of the countries have not yet approved invasive phage therapy in humans. Phage derived enzymes can also be used, but the dose of administration requires proper calibration. Moreover, rapid identification of susceptible phages is required for implementation of phage therapy, especially against secondary infections and AMR bacteria. Phage libraries, screening platforms and phage banks need to be established for effective phage therapies. There is also lack of awareness about bacteriophages therapy because of limited clinical trials demonstrating its effectiveness and therapeutic cGMP preparation (current Good Manufacturing Practice $)^{[124]}$. Also, phage resistance has been observed during single phage application, but it can be surpassed when a cocktail of phages is used in a sequential approach of administration along with standardized formulation and dosage ${ }^{[60]}$.

\section{CONCLUSION}

The COVID-19 pandemic is a striking health crisis throughout the globe threatening the survival of humanity. COVID-19 patients after prolonged hospitalizations in ICUs are more vulnerable to SARS-CoV-2 infection when paired with super added pulmonary infections like ventilator-associated pneumonia, bacteremia with sepsis caused by MDR nosocomial pathogens resulting in respiratory failure and death. Broad-spectrum antibiotics are generally recommended to keep these infections at bay especially in ICUs, which is further stimulating AMR. The irrational use, ill-effects of antibiotics and a lack of treatment options for MDR bacterial infections has led to resurgence of phage therapy alone or in synergism with antibiotics as one of the most promising option for treating bacterial infections in this era of AMR. Bacteriophages and their lytic enzymes have shown great potential in the treatment of bacterial infections and studies have also indicated phage mediated antiviral immunity by lowering NF- $\kappa \mathrm{B}$ activation, ROS generation, along with the production of antibodies via phage display vaccines. Bacteriophage therapy can thus serve as a double edge sword to avert an emerging healthcare crunch from COVID-19 and multi drug resistant pulmonary bacterial infections. However, further exploration is needed to ensure safety protocols and efficacy in order to meet the challenges in phage therapy and develop appropriate regulations for its clinical use in prevention and management of current and future pandemics.

\section{Conflict of interests:}

The authors declared no conflicts of interest.

\section{REFERENCES}

1. Manohar P, Loh B, Athira S, Nachimuthu R, Hua X, Welburn $\mathrm{SC}$, et al. Secondary bacterial infections during pulmonary viral disease: phage therapeutics as alternatives to antibiotics?. Front Microbiol 2020;11:1434.

2. Li X, Geng M, Peng Y, Meng L, Lu S. Molecular immune pathogenesis and diagnosis of COVID-19. J Pharm Anal 2020;10(2):102-8.

3. WHO Coronavirus (COVID-19) Dashboard. World Health Organisation 2021.

4. Fu Y, Yang Q, Xu M, Kong H, Chen H, Fu Y, et al. Secondary bacterial infections in critical ill patients of COVID-19. Open Forum Infect Dis 2020;7(6):ofaa220.

5. Morens DM, Taubenberger JK, Fauci AS. Predominant role of bacterial pneumonia as a cause of death in pandemic influenza: implications for pandemic influenza preparedness. J Infect Dis 2008;198(7):962-70.

6. Zahariadis G, Gooley TA, Ryall P, Hutchinson C, Latchford MI, Fearon MA, et al. Risk of ruling out severe acute respiratory syndrome by ruling in another diagnosis: Variable incidence of 
atypical bacteria coinfection based on diagnostic assays. Can Respir J 2006;13(1):17-22.

7. Langford BJ, So M, Raybardhan S, Leung V, Westwood D, MacFadden DR, et al. Bacterial co-infection and secondary infection in patients with COVID-19: a living rapid review and meta-analysis. Clin Microbiol Infect 2020;1622-29.

8. Zhou F, Yu T, Du R, Fan G, Liu Y, Liu Z, et al. Clinical course and risk factors for mortality of adult inpatients with COVID-19 in Wuhan, China: a retrospective cohort study. Lancet 2020;395:1054-62.

9. Prabhurajeshwar C, Desai PP, Waghmare T, Rashmi SB. An overview of bacteriophage therapy over antibiotics; as an alternative for controlling bacterial infections. Int J Pharm Sci Res 2020;11(3):993-6.

10. Lin DM, Koskella B, Lin HC. Phage therapy: An alternative to antibiotics in the age of multi-drug resistance. World $\mathrm{J}$ Gastrointest Pharmacol Ther 2017;8(3):162-73.

11. Bengoechea JA, Bamford CGG. SARS-CoV-2, bacterial coinfections and AMR: the deadly trio in COVID-19? EMBO Mol Med 2020;12(7):e12560.

12. Feldman C, Anderson R. The role of co-infections and secondary infections in patients with COVID-19. Pneumonia 2021;13(1):1-15.

13. Nag VL, Kaur N. Superinfections in COVID-19 Patients: Role of Antimicrobials. Dubai Med J 2021;4:117-26.

14. Garcia-Vidal C, Sanjuan G, Moreno-García E, Puerta-Alcalde $\mathrm{P}$, Garcia-Pouton N, Chumbita M, et al. Incidence of coinfections and superinfections in hospitalized patients with COVID-19: a retrospective cohort study. Clin Microbiol Infect 2020;27(1):83-8.

15. Sharifipour E, Shams S, Esmkhani M, Khodadadi J, FotouhiArdakani R, Koohpaei A, et al. Evaluation of bacterial coinfections of the respiratory tract in COVID-19 patients admitted to ICU. BMC Infect Dis 2020;20(1):1-7.

16. Bustamante-Marin XM, Ostrowski LE. Cilia and Mucociliary Clearance. Cold Spring Harb Perspect Biol 2017;9(4):a028241.

17. Kim YG, Park JH, Reimer T, Baker DP, Kawai T, Kumar H, et al. Viral infection augments Nod $1 / 2$ signaling to potentiate lethality associated with secondary bacterial infections. Cell Host Microbe 2011;9(6):496-507.

18. Chertow DS, Memoli MJ. Bacterial coinfection in Influenza: a grand rounds review. JAMA 2013;309(3):275-82.

19. Ghoneim HE, Thomas PG, McCullers JA. Depletion of alveolar macrophages during influenza infection facilitates bacterial superinfections. J Immunol 2013;191(3):1250-9.

20. Wang H, Anthony D, Selemidis S, Vlahos R, Bozinovski S. Resolving Viral-Induced Secondary Bacterial Infection in COPD: A Concise Review. Front Immunol 2018;9:2345.

21. Antibiotic/Antimicrobial Resistance (AR/AMR). Centers for Disease Control and Prevention, National Center for Emerging and Zoonotic Infectious Diseases; 2021.

22. MacIntyre CR, Bui CM. Pandemics, public health emergencies and antimicrobial resistance-putting the threat in an epidemiologic and risk analysis context. Arch Public Health 2017;75(1):1-6.

23. Cauley LS, Vella AT. Why is co-infection with influenza virus and bacteria so difficult to control?. Discov Med 2015;19(102):33-40.

24. Sun K, Yajjala VK, Bauer C, Talmon GA, Fischer KJ, Kielian $\mathrm{T}$, et al. Nox2-derived oxidative stress results in inefficacy of antibiotics against post-influenza $S$. aureus pneumonia. J Exp Med 2016;213(9):1851-64.

25. Morris DE, Cleary DW, Clarke SC. Secondary bacterial infections associated with influenza pandemics. Front Microbiol 2017;8:1041.

26. Mirzaei R, Goodarzi P, Asadi M, Soltani A, Aljanabi HA, Jeda AS, et al. Bacterial co-infections with SARS-CoV-2. IUBMB Life 2020;72(10):2097-111.

27. Crotty MP, Meyers S, Hampton N, Bledsoe S, Ritchie DJ, Buller RS, et al. Epidemiology, co-infections and outcomes of viral pneumonia in adults: an observational cohort study. Medicine 2015;94(50):e2332.

28. Luciani M, Bentivegna E, Spuntarelli V, Lamberti PA, Cacioli G, Del Porto F, et al. Recurrent COVID-19 pneumonia in the course of chemotherapy: Consequence of a weakened immune system? J Med Virol 2021;93:1882-4.

29. Bogossian EG, Taccone FS, Izzi A, Yin N, Garufi A, Hublet $\mathrm{S}$, et al. The acquisition of multidrug-resistant bacteria in patients admitted to COVID-19 intensive care units: a monocentric retrospective case control study. Microorganisms 2020;8(11):1821.

30. Patel A, Emerick M, Cabunoc MK, Williams MH, Preas MA, Schrank G, et al. Rapid spread and control of multidrugresistant Gram-negative bacteria in COVID-19 patient care units. Emerg Infect Dis 2021;27(4):1234-7.

31. Sun K, Metzger DW. Influenza and Staphylococcus aureus coinfection: TLR9 at play. Trends Microbiol 2019;27(5):3834.

32. Iverson AR, Boyd KL, McAuley JL, Plano LR, Hart ME, McCullers JA. Influenza virus primes mice for pneumonia from Staphylococcus aureus. J Infect Dis 2011;203(6):880-8.

33. Finelli L, Fiore A, Dhara R, Brammer L, Shay DK, Kamimoto L, et al. Influenza-associated pediatric mortality in the United States: increase of Staphylococcus aureus coinfection. Pediatrics 2008;122(4):805-11.

34. Reed C, Kallen AJ, Patton M, Arnold KE, Farley MM, Hageman $\mathrm{J}$, et al. Infection with community-onset Staphylococcus aureus and Influenza virus in hospitalized children. Pediatr Infect Dis J 2009;28(7):572-6.

35. Palacios G, Hornig M, Cisterna D, Savji N, Bussetti AV, Kapoor $\mathrm{V}$, et al. Streptococcus pneumoniae coinfection is correlated with the severity of H1N1 pandemic influenza. PLoS One 2009;4(12):e8540.

36. Ochi F, Tauchi H, Jogamoto T, Miura H, Moritani T, Nagai $\mathrm{K}$, et al. Sepsis and pleural empyema caused by Streptococcus pyogenes after Influenza a virus infection. Case Rep Pediatr 2018;2018:4509847.

37. Wang XY, Kilgore PE, Lim KA, Wang SM, Lee J, Deng W, et al. Influenza and bacterial pathogen coinfections in the $20^{\text {th }}$ century. Interdiscip Perspect Infect Dis 2011;2011:146376.

38. Mina MJ, Burke RM, Klugman KP. Estimating the prevalence of coinfection with influenza virus and the atypical bacteria Bordetella pertussis, Chlamydophila pneumoniae and Mycoplasma pneumoniae. Eur J Clin Microbiol Infect Dis 2014;33(9):1585-9.

39. Gao HN, Lu HZ, Cao B, Du B, Shang H, Gan JH, et al. Clinical findings in 111 cases of Influenza A (H7N9) virus infection. N Engl J Med 2013;368(24):2277-85.

40. Wolf DG, Greenberg D, Shemer-Avni Y, Givon-Lavi N, BarZiv J, Dagan R. Association of human metapneumovirus with radiologically diagnosed community-acquired alveolar pneumonia in young children. J Pediatr 2010;156(1):115-20.

41. Van Ewijk BE, Wolfs TF, Aerts PC, Van Kessel KP, Fleer A, Kimpen JL, et al. RSV mediates Pseudomonas aeruginosa binding to cystic fibrosis and normal epithelial cells. Pediatr Res 2007;61(4):398-403. 
42. Korppi M, Leinonen M, Makela PH, Launiala K. Mixed infection is common in children with respiratory adenovirus infection. Acta Pediatr Scand 1991;80(4):413-7.

43. Korppi M, Leinonen M, Makela PH, Launiala K. Bacterial involvement in parainfluenza virus infection in children. Scand J Infect Dis 1990;22(3):307-12.

44. Tong J, Fu Y, Meng F, Kruger N, Valentin-Weigand P, Herrler G. The Sialic Acid Binding Activity of Human Parainfluenza Virus 3 and Mumps Virus Glycoproteins Enhances the Adherence of Group B Streptococci to HEp-2 Cells. Front Cell Infect Microbiol 2018;8:280.

45. El Baroudy NR, El Refay AS, Hamid TAA, Hassan DM, Soliman MS, Sherif L. Respiratory viruses and atypical bacteria co-infection in children with acute respiratory infection. Open Access Maced J Med Sci 2018;6(9):1588-93.

46. Katiyar R, Agarwal V, Chowdhary S, Srivastava N, Gaur P, Dhole TN. Incidence of human Rhinovirus coinfection with Staphylococcus aureus among HIV patients suffering from flu like illness. Int J Pharm Sci Res 2017;8(10):4441-6.

47. Yap FH, Gomersall CD, Fung KS, Ho PL, Ho OM, Lam PK, et al. Increase in methicillin-resistant Staphylococcus aureus acquisition rate and change in pathogen pattern associated with an outbreak of severe acute respiratory syndrome. Clin Infect Dis 2004;39(4):511-6.

48. Bassetti S, Bischoff WE, Sherertz RJ. Outbreak of methicillinresistant Staphylococcus aureus infection associated with an outbreak of severe acute respiratory syndrome. Clin Infect Dis 2005;40(4):633-4.

49. Alfaraj SH, Al-Tawfiq JA, Altuwaijri TA, Memish ZA. Middle East Respiratory Syndrome Coronavirus and pulmonary tuberculosis coinfection: implications for infection control. Intervirology 2017;60(1-2):53-5.

50. Khurana S, Singh P, Sharad N, Kiro VV, Rastogi N, Lathwal A, et al. Profile of co-infections \& secondary infections in COVID-19 patients at a dedicated COVID-19 facility of a tertiary care Indian hospital: Implication on antimicrobial resistance. Ind J Med Microbiol 2020;39(2):147-53.

51. Bordi L, Nicastri E, Scorzolini L, Di Caro A, Capobianchi MR, Castilletti C, et al. Differential diagnosis of illness in patients under investigation for the novel coronavirus (SARS-CoV-2), Italy, February 2020. Euro Surveill 2020;25(8):2000170.

52. Duployez C, Le Guern R, Tinez C, Lejeune AL, Robriquet L, Six $\mathrm{S}$, et al. Panton-valentine leukocidin-secreting Staphylococcus aureus pneumonia complicating COVID-19. Emerg Infect Dis 2020;26(8):1939-41.

53. Kolenda C, Ranc AG, Boisset S, Caspar Y, Carricajo A, Souche A, et al. Assessment of Respiratory Bacterial Coinfections Among Severe Acute Respiratory Syndrome Coronavirus 2-Positive Patients Hospitalized in Intensive Care Units Using Conventional Culture and BioFire, FilmArray Pneumonia Panel Plus Assay. Open Forum Infect Dis 2020;7(11):ofaa484.

54. Wang D, Hu B, Hu C, Zhu F, Liu X, Zhang J, et al. Clinical characteristics of 138 hospitalized patients with 2019 novel coronavirus-infected pneumonia in Wuhan, China. JAMA 2020;323(11):1061-9.

55. Shafran N, Shafran I, Ben-Zvi H, Sofer S, Sheena L, Krause I, et al. Secondary bacterial infection in COVID-19 patients is a stronger predictor for death compared to Influenza patients. Sci Rep 2021;11(1):12703.

56. d'Humières C, Patrier J, Lortat-Jacob B, Tran-Dinh A, Chemali $\mathrm{L}$, Maataoui $\mathrm{N}$, et al. Two original observations concerning bacterial infections in COVID-19 patients hospitalized in intensive care units during the first wave of the epidemic in
France. Plos one 2021;16(4):e0250728.

57. Cataño-Correa JC, Cardona-Arias JA, Porras Mancilla JP, García MT. Bacterial superinfection in adults with COVID-19 hospitalized in two clinics in Medellín-Colombia, 2020. Plos one 2021;16(7):e0254671.

58. Vijay S, Bansal N, Rao BK, Veeraraghavan B, Rodrigues $\mathrm{C}$, Wattal C, et al. Secondary Infections in Hospitalized COVID-19 Patients: Indian Experience. Infect Drug Resist 2021;14:1893-903.

59. Karami Z, Knoop BT, Dofferhoff AS, Blaauw MJ, Janssen NA, van Apeldoorn M, et al. Few bacterial co-infections but frequent empiric antibiotic use in the early phase of hospitalized patients with COVID-19: results from a multicentre retrospective cohort study in The Netherlands. Infect Dis 2021;53(2):102-10.

60. Principi N, Silvestri E, Esposito S. Advantages and limitations of bacteriophages for the treatment of bacterial infections. Front Pharmacol 2019; 10:513.

61. Domingo-Calap P, Delgado-Martinez J. Bacteriophages: protagonists of a post-antibiotic era. Antibiotics 2018;7(3):66.

62. Kortright KE, Chan BK, Koff JL, Turner PE. Phage therapy: a renewed approach to combat antibiotic-resistant bacteria. Cell Host Microbe 2019;25(2):219-32.

63. Mishra VN, Kumari N, Pathak A, Chaturvedi RK, Gupta AK, Chaurasia RN. Possible Role for Bacteriophages in the Treatment of SARS-CoV-2 Infection. Int $\mathrm{J}$ Microbiol 2020;2020:8844963.

64. Clokie MR, Millard AD, Letarov AV, Heaphy S. Phages in nature. Bacteriophage 2011;1(1):31-45.

65. Wojewodzic MW. Bacteriophages could be a potential game changer in the trajectory of coronavirus disease (COVID-19). Phage 2020;1(2):60-5.

66. Young R. Phage lysis: do we have the hole story yet?. Curr Opin Microbiol 2013;16(6):790-7.

67. Howard-Varona C, Hargreaves KR, Abedon ST, Sullivan MB. Lysogeny in nature: mechanisms, impact and ecology of temperate phages. ISME J 2017;11(7):1511-20.

68. Griffiths AJF, Miller JH, Suzuki DT, Lewontin RC, Gelbart WM. An Introduction to Genetic Analysis. 7th ed. New York: W. H. Freeman; 2000.

69. Benam KH, Gilchrist S, Kleensang A, Satz AB, Willett C, Zhang Q. Exploring new technologies in biomedical research. Drug Discov Today 2019;24(6):1242-7.

70. Waters EM, Neill DR, Kaman B, Sahota JS, Clokie MR, Winstanley $\mathrm{C}$, et al. Phage therapy is highly effective against chronic lung infections with Pseudomonas aeruginosa. Thorax 2017;72(7):666-7.

71. Hua Y, Luo T, Yang Y, Dong D, Wang R, Wang Y, et al. Phage therapy as a promising new treatment for lung infection caused by Carbapenem-resistant Acinetobacter baumannii in mice. Front Microbiol 2017;8:2659.

72. Kvachadze L, Balarjishvili N, Meskhi T, Tevdoradze E, Skhirtladze N, Pataridze T, et al. Evaluation of lytic activity of Staphylococcal bacteriophage Sb-1 against freshly isolated clinical pathogens. Microb Biotechnol 2011;4(5):643-50.

73. Adaptive Phage Therapeutics, Inc. (2020). Expanded access study of phage treatment in COVID-19 patients on antimicrobials for pneumonia or bacteremia/septicemia due to $A$. baumannii, $P$. aeruginosa or $S$. aureus.

74. Duplessis C, Warawa JM, Lawrenz MB, Henry M, Biswas B. Successful Intratracheal Treatment of Phage and Antibiotic Combination Therapy of a Multi-Drug Resistant Pseudomonas aeruginosa Murine Model. Antibiotics 2021;10(8):946. 
75. Maddocks S, Fabijan AP, Ho J, Lin RC, Ben Zakour NL, Dugan C, et al. Bacteriophage therapy of ventilator-associated pneumonia and empyema caused by Pseudomonas aeruginosa. Am J Respir Crit Care Med 2019;200(9):1179-81.

76. Wang J, Hu B, Xu M, Yan Q, Liu S, Zhu X, et al. Use of bacteriophage in the treatment of experimental animal bacteremia from imipenem-resistant Pseudomonas aeruginosa. Int J Mol Med 2006;17(2):309-17.

77. Kutateladze A, Adamia R. Phage therapy experience at the Eliava Institute. Med Mal Infect 2008;38(8):426-30.

78. Kamal F, Dennis JJ. Burkholderia cepacia complex phageantibiotic synergy (PAS): antibiotics stimulate lytic phage activity. Appl Environ Microbiol 2015;81(3):1132-8.

79. Semler DD, Goudie AD, Finlay WH, Dennis JJ. Aerosol phage therapy efficacy in Burkholderia cepacia complex respiratory infections. Antimicrob Agents Chemother 2014;58(7):400513.

80. Matinkhoo S, Lynch KH, Dennis JJ, Finlay WH, Vehring R. Spray-dried respirable powders containing bacteriophages for the treatment of pulmonary infections. J Pharm Sci 2011;100(12):5197-205.

81. Chhibber S, Kaur S, Kumari S. Therapeutic potential of bacteriophage in treating Klebsiella pneumoniae B5055mediated lobar pneumonia in mice. J Med Microbiol 2008;57(12):1508-13.

82. Hesse S, Malachowa N, Porter AR, Freedman B, Kobayashi SD, Gardner DJ, et al. Bacteriophage Treatment Rescues Mice Infected with Multidrug-Resistant Klebsiella pneumoniae ST258. Mbio 2021;12(1):e00034-21.

83. Wu N, Dai J, Guo M, Li J, Zhou X, Li F, et al. Pre-optimized phage therapy on secondary Acinetobacter baumannii infection in four critical COVID-19 patients. Emerg Microbes Infect 2021;10(1):612-8.

84. $\mathrm{Wu} \mathrm{M}, \mathrm{Hu} \mathrm{K}$, Xie Y, Liu Y, Mu D, Guo H, et al. A novel phage PD-6A3 and its endolysin Ply6A3, with extended lytic activity against Acinetobacter baumannii. Front Microbiol 2019;9:3302.

85. Leshkasheli L, Kutateladze M, Balarjishvili N, Bolkvadze $\mathrm{D}$, Save J, Oechslin F, et al. Efficacy of newly isolated and highly potent bacteriophages in a mouse model of extensively drug-resistant Acinetobacter baumannii bacteraemia. J Glob Antimicrob Resist 2019;19:255-61.

86. Lood R, Winer BY, Pelzek AJ, Diez-Martinez R, Thandar $\mathrm{M}$, Euler CW, et al. Novel phage lysin capable of killing the multidrug-resistant gram-negative bacterium Acinetobacter baumannii in a mouse bacteremia model. Antimicrob Agents Chemother 2015;59(4):1983-91.

87. Briers Y, Walmagh M, Van Puyenbroeck V, Cornelissen A, Cenens W, Aertsen A, et al. Engineered endolysin-based "Artilysins" to combat multidrug-resistant gram-negative pathogens. MBio 2014;5(4):e01379-14.

88. Dufour N, Debarbieux L, Fromentin M, Ricard JD. Treatment of highly virulent extraintestinal pathogenic Escherichia coli pneumonia with bacteriophages. Crit Care Med 2015;43(6):e190-8.

89. Furi L, Crawford LA, Rangel-Pineros G, Manso AS, Croix MDS, Haigh RD, et al. Methylation warfare: interaction of pneumococcal bacteriophages with their host. J Bacteriol 2019;201(19):e00370-19.

90. Ronda C, López R, García E. Isolation and characterization of a new bacteriophage, $\mathrm{Cp}-1$, infecting Streptococcus pneumoniae. J Virol 1981;40(2):551-9.

91. Loeffler JM, Fischetti VA. Synergistic lethal effect of a combination of phage lytic enzymes with different activities on penicillin-sensitive and penicillin-resistant Streptococcus pneumoniae strains. Antimicrob Agents Chemother 2003;47(1):375-7.

92. Díez-Martínez R, De Paz HD, García-Fernández E, Bustamante N, Euler CW, Fischetti VA, et al. A novel chimeric phage lysin with high in vitro and in vivo bactericidal activity against Streptococcus pneumoniae. J Antimicrob Chemother 2015;70(6):1763-73.

93. Petrovic Fabijan A, Lin RCY, Ho J, Maddocks S, Ben Zakour NL, Iredell JR; Westmead Bacteriophage Therapy Team. Safety of bacteriophage therapy in severe Staphylococcus aureus infection. Nat Microbiol 2020;5(3):465-72.

94. Prazak J, Valente L, Iten M, Grandgirard D, Leib SL, Jakob $\mathrm{SM}$, et al. Nebulized Bacteriophages for Prophylaxis of Experimental Ventilator-Associated Pneumonia Due to Methicillin-Resistant Staphylococcus aureus. Crit Care Med 2020;48(7):1042-6.

95. Lehman SM, Mearns G, Rankin D, Cole RA, Smrekar F, Branston SD, et al. Design and Preclinical Development of a Phage Product for the Treatment of Antibiotic-Resistant Staphylococcus aureus Infections. Viruses 2019;11(1):88.

96. Kirby AE. Synergistic action of gentamicin and bacteriophage in a continuous culture population of Staphylococcus aureus. PLoS One 2012;7(11):e51017.

97. Gu J, Xu W, Lei L, Huang J, Feng X, Sun C, et al. LysGH15, a novel bacteriophage lysin, protects a murine bacteremia model efficiently against lethal methicillin-resistant Staphylococcus aureus infection. J Clin Microbiol 2011;49(1):111-7.

98. Daniel A, Euler C, Collin M, Chahales P, Gorelick KJ, Fischetti VA. Synergism between a novel chimeric lysin and oxacillin protects against infection by methicillin-resistant Staphylococcus aureus. Antimicrob Agents Chemother 2010;54(4):1603-12.

99. Jun SY, Jung GM, Yoon SJ, Oh MD, Choi YJ, Lee WJ, et al. Antibacterial properties of a pre-formulated recombinant phage endolysin, SAL-1. Int J Antimicrob Agents 2013;41(2):156-61.

100. Gilmer DB, Schmitz JE, Euler CW, Fischetti VA. Novel bacteriophage lysin with broad lytic activity protects against mixed infection by Streptococcus pyogenes and methicillinresistant Staphylococcus aureus. Antimicrob Agents Chemother 2013;57(6):2743-50.

101. Akturk E, Oliveira H, Santos SB, Costa S, Kuyumcu S, Melo LDR, et al. Synergistic Action of Phage and Antibiotics: Parameters to Enhance the Killing Efficacy Against Mono and Dual-Species Biofilms. Antibiotics (Basel) 2019;8(3):103.

102. Aslam S, Courtwright AM, Koval C, Lehman SM, Morales $\mathrm{S}$, Furr CL, et al. Early clinical experience of bacteriophage therapy in 3 lung transplant recipients. Am J Transplant 2019;19(9):2631-9.

103. Chan BK, Turner PE, Kim S, Mojibian HR, Elefteriades JA, Narayan D. Phage treatment of an aortic graft infected with Pseudomonas aeruginosa. Evol Med Public Health 2018;2018(1):60-6.

104. Luscher A, Simonin J, Falconnet L, Valot B, Hocquet D, Chanson $\mathrm{M}$, et al. Combined Bacteriophage and Antibiotic Treatment Prevents Pseudomonas aeruginosa Infection of Wild Type and cftr- Epithelial Cells. Front Microbiol 2020;11:1947.

105. Van Belleghem, JD, Clement F, Merabishvili M, Lavigne R, Vaneechoutte M. Pro-and anti-inflammatory responses of peripheral blood mononuclear cells induced by Staphylococcus aureus and Pseudomonas aeruginosa phages. Sci Rep 2017;7(1):8004. 
106. Fenton M, McAuliffe O, O’Mahony J, Coffey A. Recombinant bacteriophage lysins as antibacterials. Bioeng Bugs 2010;1(1):9-16.

107. Vázquez R, García E, García P. Phage lysins for fighting bacterial respiratory infections: a new generation of antimicrobials. Front Immunol 2018;9:2252.

108. Larpin Y, Oechslin F, Moreillon P, Resch G, Entenza JM, Mancini S. In vitro characterization of PlyE146, a novel phage lysin that targets Gram-negative bacteria. PLoS One 2018;13(2):e0192507.

109. Górski A, Bollyky PL, Przybylski M, Borysowski J, Międzybrodzki R, Jończyk-Matysiak E, et al. Perspectives of phage therapy in non-bacterial infections. Front Microbiol 2019;9:3306.

110. Chappell JD, Dermody TS. Biology of viruses and viral diseases. Mandell Douglas Bennett's Principles Pract Infect Dis 2015:1681-93.

111. Sanders JM, Monogue ML, Jodlowski TZ, Cutrell JB. Pharmacologic treatments for Coronavirus disease 2019 (COVID-19): a review. JAMA 2020;323(18):1824-36.

112. Wiersinga WJ, Rhodes A, Cheng AC, Peacock SJ, Prescott HC. Pathophysiology, transmission, diagnosis and treatment of Coronavirus disease 2019 (COVID-19): a review. JAMA 2020;324(8):782-93.

113. Meek ES, Takahashi M. Differential inhibition by phagicin of DNA synthesis in cells infected with vaccinia. Nature 1968;220(5169):822.

114. Kircheis R, Haasbach E, Lueftenegger D, Heyken WT, Ocker M, Planz O. NF- $\kappa$ B pathway as a potential target for treatment of critical stage COVID-19 patients. Front Immunol 2020;11:3446.

115. Górski A, Międzybrodzki R, Żaczek M, Borysowski J. Phages in the fight against COVID-19? Future Microbiol 2020;15:1095-100.

116. Paiva CN, Bozza MT. Are reactive oxygen species always detrimental to pathogens? Antioxid Redox Signal 2014;20(6):1000-37.

117. Miedzybrodzki R, Fortuna W, Weber-Dabrowska B, Gorski A. Bacterial viruses against viruses pathogenic for man? Virus Res 2005;110(1-2):1-8.

118. Aghebati-Maleki L, Bakhshinejad B, Baradaran B, Motallebnezhad M, Aghebati-Maleki A, Nickho H, et al. Phage display as a promising approach for vaccine development. $\mathbf{J}$ Biomed Sci 2016;23(1):1-8.

119. Zalewska-Piątek B, Piątek R. Bacteriophages as Potential Tools for Use in Antimicrobial Therapy and Vaccine Development. Pharmaceuticals 2021;14(4):331.

120. Clementi N, Criscuolo E, Castelli M, Clementi M. Broad-range neutralizing anti-influenza A human monoclonal antibodies: new perspectives in therapy and prophylaxis. New Microbiol 2012;35(4):399-406.

121. Thompson J, Pope T, Tung JS, Chan C, Hollis G, Mark $\mathrm{G}$, et al. Affinity maturation of a high-affinity human monoclonal antibody against the third hypervariable loop of human immunodeficiency virus: use of phage display to improve affinity and broaden strain reactivity. J Mol Biol 1996;256(1):77-88.

122. Huo J, Le Bas A, Ruza RR, Duyvesteyn HM, Mikolajek H, Malinauskas $\mathrm{T}$, et al. Neutralizing nanobodies bind SARSCoV-2 spike RBD and block interaction with ACE2. Nat Struct Mol Biol 2020;27(9):846-54.

123. Li W, Drelich A, Martinez DR, Gralinski L, Chen C, Sun Z, et al. Potent neutralization of SARS-CoV-2 in vitro and in an animal model by a human monoclonal antibody. BioRxiv 2020.

124. Mutti M, Corsini L. Robust approaches for the production of active ingredient and drug product for human phage therapy. Front Microbiol 2019;10:2289. 